\title{
Mapungubwe: Interpretation of the Gold Content OF THE ORIGINAL GOLD BURIAL M1, A620
}

\author{
Alex Duffey
}

\begin{abstract}
This paper is an attempt to give a credible interpretation of the many gold foil fragments found in a single grave on the summit of Mapungubwe Hill in January 1933. While carefully studying the many fragments of gold foil and the restored rhino, bovine and feline from the Mapungubwe collection at the University of Pretoria, the author noticed that the same type of images, symbols and shapes are found on the rim and base of an old divining bowl at present at Groote Schuur in Cape Town, as well as on more recent BaVenda divining bowls. It was also apparent that the Mapungubwe gold rhi-no, bovine and feline are all relatively of the same size, that they all have curved bodies and that all have flared feet with small tack holes at their bases, indicating that they were likely once attached to a flat round wooden surface. Along with the remains of a crocodile once in Dr Marc Smalle's collection in Polokwane, all these figurines came from a single grave on Mapungubwe Hill, referred to as the Original Gold Burial M1, A620. It is argued that all the fragments were once attached to a single object, namely an elaborately carved wooden divining bowl which had disintegrated over time. While the complete collection of gold foil fragments recovered in the 1930s may have allowed a relatively accurate reconstruction of the appearance of the vessel which they originally covered, many of these are missing and therefore this is unfortunately not possible. Enough fragments remain, however, to give a credible partial reconstruction of the bowl based on careful iconographic observation.
\end{abstract}

\section{Résumé}

Cette étude est une tentative d'interprétation crédible des multiples fragments de feuille d'or trouvés dans une seule tombe sur le sommet de Mapungubwe en janvier 1933. Tandis qu'il étudiait avec soin ces fragments de feuilles d'or ainsi que le rhinocéros, le bovin et le félin restaurés de la collec-tion Mapungwube de l'Université de Pretoria, l'auteur s'est rendu compte que les mêmes imageries, symboles et formes se retrouvaient sur le rebord et la base d'un vieux bol divi-natoire actuellement conservé à Groot Schurr au Cap, ainsi que sur des bols divinatoires BaVenda plus récents. Il est également visible que le rhinocéros, le bovin et le félin en or de Mapungwube sont tous trois de taille identique, qu'ils ont des corps arrondis et que leurs pattes se terminent de façon évasée avec de petites perforations à la base, ce qui indique qu'il était possible qu'ils fussent à l'origine cloués sur une surface ronde en bois. Tout comme les restes d'un crocodile, jadis dans la collection du Dr Marc Smalle à Polokwane, ces figurines viennent d'une seule et même tombe sur la colline de Mapungwube, répertoriée sous le nom de The Original Gold Burial M1 A620. L'auteur propose d'envisager que tous ces fragments provenaient d'un seul objet, par exemple un bol divinatoire en bois, minutieusement ouvragé, qui se serait malheureusement désagrégé. Comme hélas la majorité des fragments originaux qui auraient recouvert un tel bol manque, il n'est pas possible de reconstruire ce bol à l'image de ce qu'il était à l'origine avec fidélité. Toutefois, il reste assez de fragments disponibles pour en faire une reconstruction partielle crédible, basée sur une observation iconographique minutieuse.

Keywords: Mapungubwe, divination, Zimbabwe zodiac bowls, BaVenda divining bowls, gold rhinoceros, gold foil fragments

Alex Duffe alexander.duffey@gmail.com

Emeritus Professor, University of Pretoria, Pretoria 0001, South Africa 


\section{Introduction}

In many African societies divination in one form or another has played an important role as a trusted means of decision-making and an important repository of knowledge. Although divination practices vary throughout Africa, there are marked commonalities. According to PeEk (1991: 194) in many African societies divination is separated from normal discourse and dispute settlement. In all these societies diviners are greatly feared and, as communicators between worlds, they are seen to not fully belong to either realm. They normally utilize a diffuse body of esoteric knowledge to arrive at otherwise inaccessible information. A diviner manipulates divinatory vehicles and decodes their communication according to an established scheme which has remained unchanged for generations. In most African societies the final diagnosis and plan for action are rendered collectively by the diviner and the consulter and thereby divining becomes a dynamic determining process (ibid.: 193-206). According to KoFI Agorsah (2010: 52) there has always been a range of professional diviners and healers in Shona society. At the royal courts of the Rozwi, Shona and BaVenda the medicine-man proper (nganga) and the special diviner (mungoma) were principal officials, who enjoyed high status (STAYt 1968: 300). STAYT (1968: 300) notes that in BaVenda society the diviner had an influence out of all proportion to his knowledge and skill and that "he is in constant and intimate touch with the chiefs, some of whom actually belong to the fraternity". MACK (2007: 110) adds that in earlier times the most powerful diviners were from the kosi (kings) of the Singo lineage ${ }^{1}$. Diviners were not only responsible for the chief's personal health, but also had to scrutinize the intentions of people wishing to see the chief (HuffMAN 1996: 26). Huffman (1996: 26, 39, 128, 188) shows that small diviner's huts, sometimes with an exterior fire-place, were found at most of the royal courts such as Danangombe/DhloDhlo, the capital of the Changomire Rozwi, at the Khami-period palaces of Kongezi and Dzata (BaVenda), at the Great Zimbabwe Hill Ruin (Shona) and even at ancient Mapungubwe.

Unfortunately Shona and BaVenda ethnography and the archaeological record have had very little to say about the burial places of important diviners. Given that the paraphernalia of diviners such as divining dice (hakata) and divining bowls (ndilo) were mostly made of wood, much must have decayed over time in graves, very little information is likely to remain to

1 At the beginning of the $18^{\text {th }}$ century the Singo dynasty migrated to Venda via Zimbabwe, and subjugated local populations who had settled there during the previous fifteen hundred years (KRUGER 1999: 15). identify a grave as that of an important diviner. COOKE (1985: 34), however, makes mention that "two sets of divining dice have been recorded from a prehistoric Iron Age site". He mentions five pallets made of either ivory or bone, which were recovered from the Khami Hill Ruin (RoBinson 1959), and another undecorated bone set from No. 8 Ruin. Huffman (1996: 41) adds a further set of four divining dice made of hippo ivory, which was recovered from Dzata (early BaVenda) and which he considers remarkably similar to the dice found by Robinson in the Hill Ruin at Khami in Zimbabwe. Only two early divining bowls have been found, both in caves in Zimbabwe and both badly eroded by either rot or termite activity. LOUBSER (2008: 193) mentions that prior to the 1900s the Singo титиро (clans or $s i b s^{2}$ ), buried their chiefs within a mountain cave. If the two divining bowls discovered in caves in Zimbabwe had belonged to diviners of royal Singo lineage, then this possibly explains why they were placed in caves.

\section{BaVenda divining bowls}

To assist divination in most cultural contexts some type of device is usually employed and bowls filled with water are one of the most important divination devices. Such bowls are very old and in antiquity the use of such bowls was by no means uncommon (DAvis 1955: 134). Seeds are floated on the water in the bowl to allow the diviner to read "messages", interpreted by the way in which the seeds touch symbols on the bowl's rim. The diviner constructs meaningful metaphoric utterances from this pattern of symbolic messaging he/she sees in the bowl. The correct order or pattern of the configuration of symbols must be revealed in this unique way of knowing. Although the bowl divination system appears haphazard, there is an exacting analysis of the arbitrary configurations by the diviner. This opposition of modes makes the divinatory enterprise unique and effective. Consequently, the bowl divination system has an element of cosmic randomness built into it.

Large bowls (Fig. 1), carved from a solid piece of wood, $1 \frac{1}{2}$ to 2 inches deep, with a broad flat border, were recorded in use in the royal courts of the BaVenda from the $19^{\text {th }}$ century and are described as divining bowls called "ndila ya lupangwa" (bowl to be filled) or "ndila ya luf-

2 In Shona and BaVenda societies these sibs, referred to as mutupo, consisted of social units or group relationships that are based on kinship through one line of descent. Every member of these societies had to belong to such a sib and animals such as the lion, buffalo, rhinoceros, elephant, leopard, baboon, etc. normally represented them. 


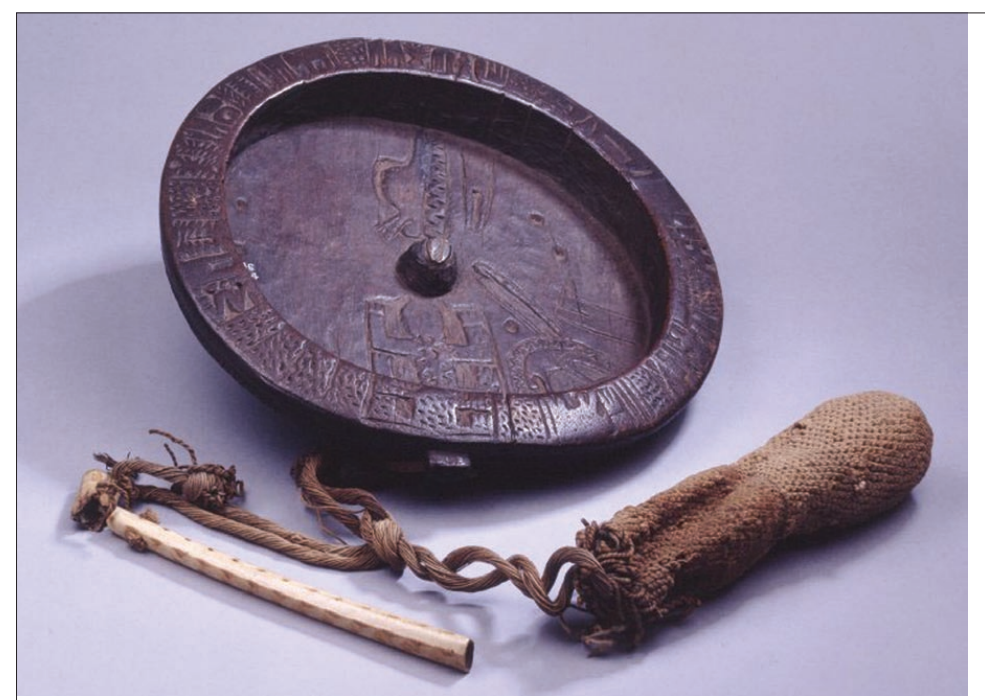

Fig. 1. Wooden BaVenda divin-ing bowl in the British Museum, Af1946 04.1a, with whistle and bag for seeds, $19^{\text {th }}$ century (photo credit: (C) Trustees of the British Museum). Note the schematic crocodile on the bed of the bowl and the animal sibs and other symbols on the wide, flat rim of the bowl.
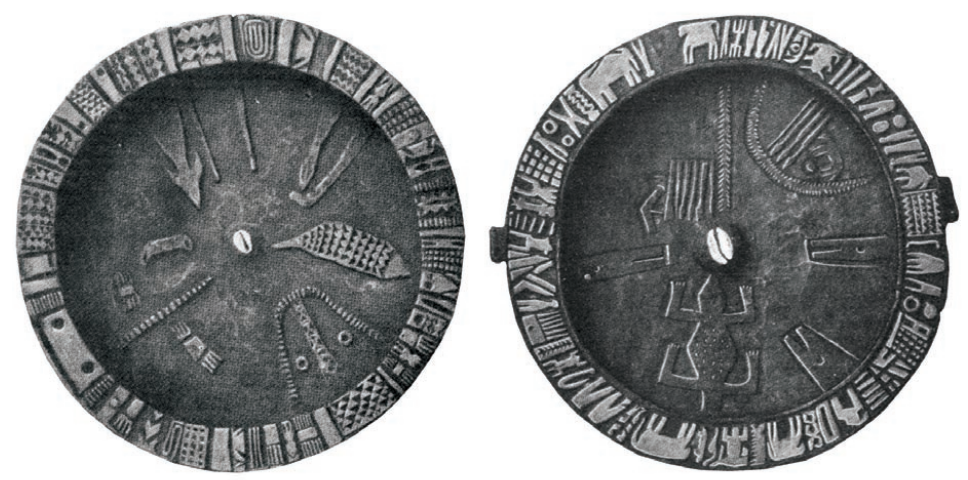

Fig. 2. Two BaVenda divining bowls illustrated by Hugh StaYT(1968: Pl. XLIII and XLIV).

hali" (bowl of the wizard) ${ }^{3}$. LoubSER (2008: 196) notes that such divination bowls were "stored within the chief's royal 'mountain' quarters" and that they were "used in public only when a big calamity threatened the well-being of the entire chiefdom, such as during severe droughts or after a death caused by lightning". The use of such bowls apparently ceased in the early $20^{\text {th }}$ century. These bowls have a wide, flat rim on which is cut, in relief, figures representing the various totem groups found among them, as well as figures representing persons and objects in tribal life. Stylistically the carved images refer to clans, gender and social rank. All these bowls have a crocodile on the bed of the bowl and are decorated on their undersides with

3 It is revealing that the BaVenda word for bowl ndilo compares closely with the Shona word ndiro for a bowl. According to Nettleton (2000: 188-189) ten of these bowls survive in Singo capitals as witness to one of the systems of divination formerly in use among the BaVenda. elaborate geometric patterns. The patterns on the underside represent ancestor spirits who live in the underworld below the assembly area, or "pool" (ibid.). These bowls have two handles and stand on a central foot.

According to Hugh STAYT (1968: 291), who made an in-depth study of BaVenda divination bowls, the mingoma (diviners) only used these bowls for "the detection of vhaloi " (wizards or wrongdoers), and, as far as he could ascertain, such bowls only occur among the BaVenda in South Africa and the BaKaranga (Western Shona) in Zimbabwe ${ }^{4}$ (Fig. 2). The BaVenda believed

4 The Yoruba diviners or babalowa of Nigeria communicate with the spirit world by using a wooden Ifa divination tray or opon ifa. This flat tray has a circular plate-like surface with a border containing various carved motifs. Such divination trays are used to determine different arrangements of signs for a specific client to establish their own meanings. 

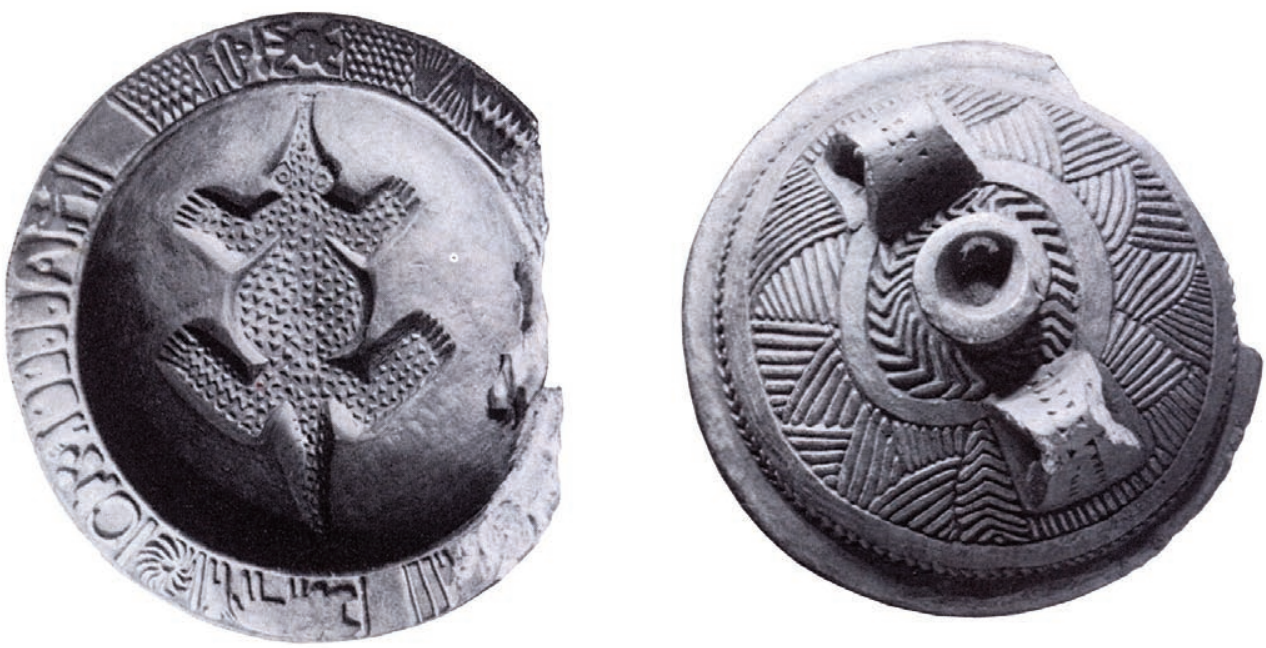

Fig. 3. Inside and underside of the so-called "Zodiac bowl" found in the 1880s in a cave near the Great Zimbabwe Ruins (photos taken by kind permission of Groote Schuur Museum).

that the vhaloi's evil machinations were responsible for most misfortunes and nearly all deaths in BaVenda society. According to MACK (2007: 110) BaVenda bowl divination was the speciality of the most powerful diviners deriving from the kosi (kings) of the Singo lineage and the iconography and method of using the bowls were related to the mythical Lake Fundudzi - the Lake of Creation. Realistic representations and other designs symbolizing different phases of the magical and religious conceptions of the BaVenda are engraved on the broad, flat borders and in the beds of the bowls. The basic symbols seem to have remained the same throughout history. The symbols on some bowls are more realistic than those on others; some symbols are very crude and roughly carved, while others are complicated in design and workmanship. Divining dice (hakata) are found among the many symbols on the rims of all these magic bowls, while the realistic animal representations on the rims are totems of the mutupo (sibs), to which every MuVenda belonged.

StaYt (1968: 291) has provided a detailed account of how the diviner used these bowls. Firstly, the mungo$m a$ (diviner) brings the bowl concealed in a skin from his hut. Before the consulter or client may look at it, his/her eyes must be treated with a white powder, otherwise he/she will turn blind. The powder, made from the droppings of the kingfisher found under water, is kept in a small horn container. When the eyes are treated, he uncovers the divining bowl. With a smaller wooden bowl it is then filled to the brim with water, which must be carried over the symbol on the rim that represents the mafhoro or entrance gate to the khoro (gathering place). The diviner then takes 4 to 6 seeds of the murutu tree from a small string bag and gives it to the consulter or client. The client or consulter drops the seeds over the mukhombo (a cowrie shell embedded as an umbilicus in the centre of the bowl). The mungoma then sniffs a seed pellet up his nose and begins to whistle on a hollow bone whistle and calls the names of different sibs. All the seeds float around the bowl and the first to touch one of the sib symbols indicates the sib or clan of the muloi (wrongdoer). The symbols at which the seeds touch the rim enable the diviner to interpret and reconstruct the event. Stayt found, however, that the diviners gave totally different interpretations to many of the symbols on the bowls and his eventual conclusion was: "All these inconsistencies bear out my suspicion that the present users of these bowls do not understand the real significance of the symbols engraved on them, but that the BaVenda came in contact with them at some early time and adapted them to their own use, gradually forgetting their original meaning and interpreting them to suit themselves. If this is the case, where did these bowls originate? I think that probably, with the divining dice, they are a relic of the ancient Zimbabwe culture" (ibid.: 299). NetTLETon's (1984) painstaking iconographical analyses of BaVenda divining bowls shows that they spring from an ancient Shona divining tradition, and LOUBSER (2008: 196) carries this link further when he notes that "ceramic similarities and Venda oral histories strongly suggest a link between the Singo chiefs and vestiges of the Zimbabwe empire of Shona-speakers".

\section{The Zimbabwe divining bowls}

As was recounted above, two early wooden divining bowls have been found in Zimbabwe. The first to be discovered (Fig. 3), called the "Crocodile platter" or "Zodiac bowl", was discovered by Edward Muller in the 1880s in a cave ten miles south-west of the Great Zimbabwe Ruins in the Nini district. When found, the 
carved wooden bowl was resting on its edge in sand and termites had eaten away part of the rim. Soon after its discovery it was given to Cecil John Rhodes and since then it has been kept at Groote Schuur in Cape Town. This bowl is approximately $112 \mathrm{~cm}$ in diameter and is made of a soft wood (Cooke 1985: 31). In an article in the Geographical Journal of April 1890, Dr Henry Schlichter maintained that the figures carved on the rim represented the twelve signs of the Zodiac and therefore it became known as the "Zodiac bowl". This identification was initially taken as supporting evidence for the theory that the ruins were Semitic in origin. This theory and the relationship of the bowl to the Zodiac have since been questioned and is now seen as incorrect. According to the curator of Groote Schuur, Dr Rayda Becker, the so-called wooden "Zodiac bowl" has "not yet been dendrochronologically dated" with the result that its age is unknown. It has been argued though that this divining bowl was most probably the possession of a Western Shona or BaKaranga diviner of the late $18^{\text {th }}$ century ${ }^{5}$.

The second divining bowl from Zimbabwe, at present in the Queen Victoria Museum in Harare, was found by Harald von Sicard in 1948 in a cave on Rubabva hill near Mnene Mission in the Mberengiva district (CoOKe 1985: 31). Although badly damaged by termites, it is possible to recognize a crocodile in the centre and an animal on the rim, as well as a complicated interwoven design on the bottom. This bowl is considered to be of a slightly later date than the one found at Great Zimbabwe.

When these early Zimbabwe bowls are compared with the more recent $\mathrm{BaVenda}$ divination bowls mentioned by STAYт (1968: 291-300), and other bowls ${ }^{6}$

5 Joseph O. Vogel has a point when he writes the following about the so-called "Zodiac bowl" in his foreword to Innocent PIKIRAYI's (2001: xvii) book The Zimbabwe Culture: Origins and Decline of Southern Zambezian States: “(James BENT [1896]) .. even went so far as to identify a common form of carved African wooden bowl as a 'zodiac' some thousands of years old. We need not belabour the point that the wood could not have survived any time at all in central African soil...". As the bowl was found in a cave in the $1880 \mathrm{~s}$, it could not have survived the elements for more than 100 years, making it to date at the earliest to the late $18^{\text {th }}$ century.

6 There is at present a beautiful BaVenda divining bowl in the possession of Professor Chris Boonzaaier of the Department of Anthropology and Archaeology of the University of Pretoria. In the British Museum there is a magnificent BaVenda divining bowl (Af1946, 04.1a) acquired from a D. Allam in 1946, who stated that he had acquired the bowl in 1911 from a diviner who had been convicted of witchcraft. In the McDermott collection of the Dallas Museum of Art there is a Ziwa divining bowl from Zimbabwe. There is also a $30 \mathrm{~cm}$ large BaVenda divining bowl in the Granger Collection in New York. such as one found by Professor N.J. van Warmelo amongst the VaLemba in the 1960s (at present in the Iziko Museum in Cape Town), then one is amazed by the similarity of the symbols and images on their rims. What seems most likely is that the form of such divination bowls was standardized in the distant past and handed down from generation to generation. The relief carvings on the rim of what is most likely the oldest Zimbabwe bowl, the "Zodiac bowl", consist of representational images of stylized humans, a bovine, a feline and an elephant, as well as abstract images of hands, rain, hakata or divining dice, a mafhoro or entrance gate to the khoro (gathering place), chevrons, a sun symbol and other unidentifiable shapes. In the centre of the bed of the bowl is a beautifully carved schematic image of a crocodile in relief. In some bowls the crocodile is pictured with its head resting on the edge of the bowl so that its body is submerged when the bowl is filled with water. The crocodile is important as it is believed always to be in contact with the ancestral spirits through deep pools. HUFFMAN (1996:28) notes that there was a metaphorical link between crocodiles and rulers, which applied to both Shona and BaVenda rulers. According to him "crocodiles are associated with rainmaking, they behave like chiefs in that they are dangerous, ferocious and fear no enemies, they live for many years and, most importantly, they can communicate with the ancestor spirit world at the bottom of deep pools (ibid.: 29). This definitive association is not only found in the divining dice and divining bowls, but is also expressed through geometric designs on several media in BaVenda court art. The bovine, chevrons and hakata carved on the rim are similar to images on soapstone carvings found at the Great Zimbabwe Ruins, and consequently make these bowls part of a long unbroken tradition ${ }^{7}$.

\section{Mapungubwe}

Mapungubwe Hill is a flat-topped sandstone hill southeast of the confluence of the Shashi and Limpopo Rivers, with an earliest occupation dating from about AD 1200. This hill has always instilled fear in local peoples. Fouché (1937: 1) notes that "They would not so much as point at it, and when it was discussed with them they kept their backs turned carefully towards it. To climb it meant certain death. It was sacred to the Great Ones...". Could this fear of Mapungubwe Hill be an indication that in the distant past it was an important ancient centre of African divination? The fear that it instilled in local peoples, the belief that they would be

7 The images of zebra and cattle motifs carved around the exterior of soapstone bowl fragments from Great Zimbabwe are reminiscent of the images on the BaVenda divining bowls. 
blinded if they gazed upon it, and the fact that there was only one entrance gate to the khoro (gathering place) seem to lend some credence to the theory ${ }^{8}$.

\section{Discovery and excavation of the Mapungubwe gold graves}

Twenty-seven graves were excavated on top of Mapungubwe Hill between 1933 and 1940 (STEYN 2007: 140). As far as is known only three of these contained gold, namely the first burial known as the Original Gold Grave M1, $A 620^{9}$, the second burial known as the Sceptre Skeleton M5, $A 619$ (field number10), and the third grave simply known as the Gold Skeleton Grave M7, A623 (field number 14). The earliest recorded "excavations" of graves on Mapungubwe Hill were probably undertaken in May 1929 by a prospecting party consisting of Richard Rorke and Barend Lottering, who opened up the grave referred to as the Chief's Grave ${ }^{10}$, but no record of what was removed exists (ScHOEMAN 2011: 92). Next, on 31 December 1932 Mr. E.A.J. van Graan, his son, J.C.O. (Jerry) van Graan, Mr. M. Venter, Mr. D.J. du Plessis and Mr. H. van der Walt, removed quantities of "sheet gold", gold beads and small golden nails from the Original Gold Burial M1, A620 in the centre of the hill (Meyer 2011: 61). Fouché (1937: 2) later recorded: "They found large pieces of plate gold, some of them shaped. These were the remains of little rhinoceroses which had consisted of thin plate gold tacked by means of little gold tacks on to some core of wood or other substance which had perished. Solid gold tails and ears, beautifully made, had likewise been tacked on to these figures...". The five original

8 According to Stayt (1968: 300) in BaVenda society the diviner or mungoma has an influence out of all proportion to his knowledge and skill and he is always in constant and intimate touch with the chief, some of whom actually belonged to the diviner's fraternity. Such diviners ruled primarily through fear and there was a special entrance to his/her court.

9 This first gold grave M1 has the Witwatersrand Accession Number A620 and was opened by Van Graan and his party with the result that very little information on this grave exists. STEYN (2007: 141) mentions only a few fragments of the calvarium of the skeleton of "a young adult, possibly around 25-45 years". A catalogue of the initial finds in UP/AGL/D/800 lists the following artifacts: An unknown quantity of gold beads; the gold bowl; gold foil fragments; arm and ankle bands of gold wire; the gold rhinoceros; the gold circlet and horn; numerous gold pins; quantities of glass beads; iron arm and leg bands; a black bowl; a small clay bowl and three clay pots

10 Rorke said under oath that the so-called Chief's Grave had four or five square polished stones on it, of about 76 to 91 centimeters in length. They pulled the stones out of the ground, but left the graves undisturbed. Lottering, who was with them, dug in a mound to the east of the entrance of the hill and found some beautiful pots. discoverers divided the spoils into five, roughly equal portions soon after discovering them.

After Jerry van Graan had notified Professor Leo Fouché (a history lecturer at the University of Pretoria) about their finds early in February 1933, the site was immediately visited by a party consisting of Professors L. Fouché and D.E. Malan, Dr L.J. Krige, Sub-Inspector G. Kruger, Mr E.V. Adams and Mr T. Bowman. The re-excavation of the same grave dug earlier by the Van Graans, now yielded more gold objects (Meyer 2011: 62). Fouché (1937: 2) mentions: “A bowl of gold plate ${ }^{11}$, which had, like the animals, been riveted to an inner core (of wood?) by golden tacks, was also found, together with a gold plate bangle and a gold circlet and sheath or point ${ }^{12} \ldots$... Then, during a subsequent expedition on 13 April 1933, trial pits and trenches on Mapungubwe Hill were dug and according to Fouché (1937: 5): “This yielded a quantity of gold plate, including a scroll like the two already in our possession, and other fragments of gold plate which looked like missing parts of the rhinoceros" (Fig. 4).

The fragments removed earlier from Mapungubwe Hill and in the possession of the five original discoverers were purchased by the University of Pretoria from 1933 onwards (Fouché 1937: 2). These included the remains of the three fragmented animal figurines, a gold rhinoceros, a gold bovine, and a gold feline. Fragments of another animal torso were found, as well as five gold bangles, gold nails, decorative gold foil which included a crocodile head — large quantities of glass beads, many iron and copper bangles, and three earthenware ceramic vessels (TILEY-NEL 2011a: 183). In this regard Fouché (1937: 2) noted: "When the different portions were eventually recovered by the writer, he found the head of a rhinoceros in possession of one, the tail and ears in that of another, the rump in that of a third member of the party. Reconstruction, in consequence, was almost impossible". Some of these

11 There is some inconsistency with the recording of the finding of the gold bowl. Fouché (1937: 2) notes here that it was found by his party during their initial excavation in February 1933. STEYN (2007: 141), however, notes that "In a letter by J.C.O. van Graan (UP/AGL/D/12) he stated that when they found the skull of the burial, they also found 'wat ons vermoed om ' $n$ kroon te wees, want dit le bo teen die kopbeen' (what we thought to be a crown, because it lay above the skull). It is interesting to note that an original plan drawing made in May 1933 of Mapungubwe's summit by Prof. van Riet Lowe, held in the Mapungubwe Museum Archive of the University of Pretoria, clearly depicts what is referred to as a gold headdress ornamentation drawing with this burial, as interpreted by the discoverers. In this drawing, the gold bowl is clearly inverted, and placed on the skull".

12 The "sheath or point" mentioned here is the horn referred to later in this document. 


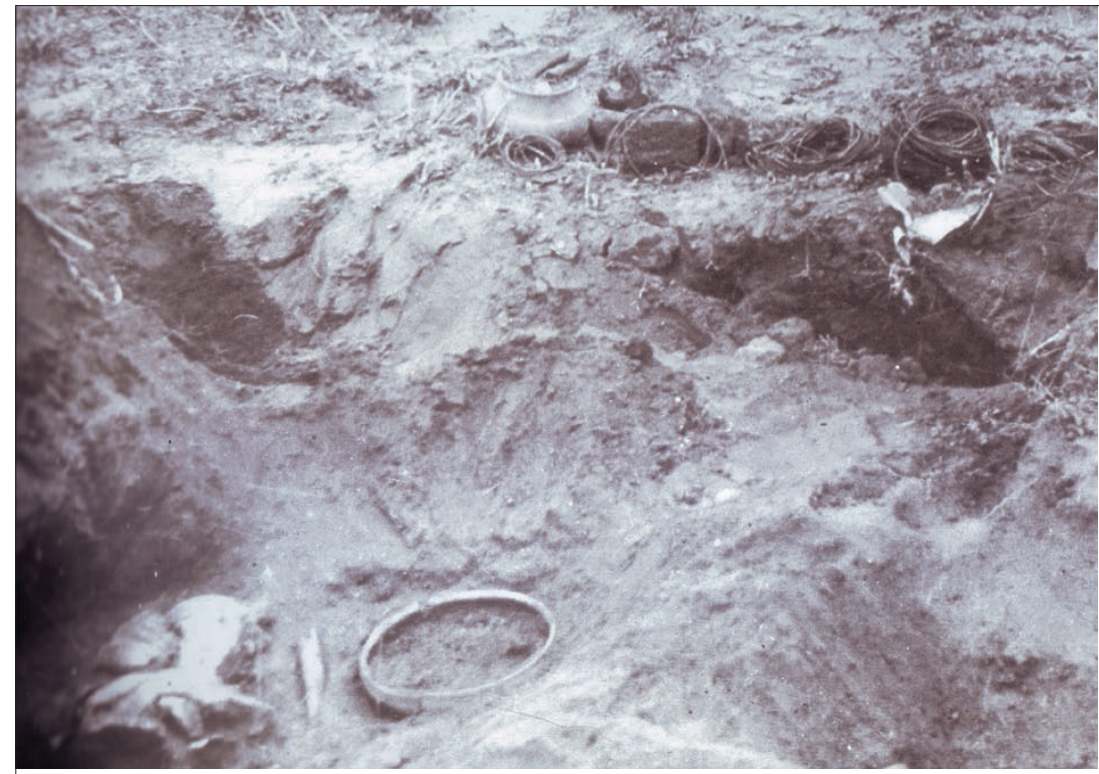

Fig. 4. Photograph taken of the Original Gold Burial M1, A620 in April 1933 (FOUCHÉ 1937).

fragments were sent to the South African Mint to be examined and cleaned by Dr Roger Pearson on 13 February 1933 (Tiley-Nel 2011a: 183). He was most probably the first person to attempt a reconstruction of the gold fragments of the gold rhinoceros (ibid.).

It appears then that the most important existing Mapungubwe gold foil fragments were unearthed by the Van Graans and company on 2 January 1933 on Mapungubwe Hill in a single grave, referred to as the Original Gold Burial M1, A620 only excluding that of the so-called "sceptre" and the later above-mentioned discoveries by Fouché's party. As the Van Graans were initially only interested in the gold, unfortunately none of the other material from the Original Gold Burial M1, $A 620$ was saved. Other fragments, such as the remains of a headless crocodile, which also came from the Original Gold Burial M1, A620, and which were still in the private collection of the late Dr Marc Smalle until 2004, must have come from other earlier discoveries on the Hill. Their whereabouts are now unknown ${ }^{13}$.

Since no written documentation of the excavation of this Original Gold Burial M1, A620 was ever produced, there is no record of the in situ position of these fragments

13 Mrs Smalle, in a telephone conversation on 16 March 2012, mentioned that she could not recollect seeing the crocodile. She mentioned that the archaeologist, Mr. Sidney Miller, whom her husband knew well, might be able to help. In e-mail correspondence with Miller on 22 March 2012, he, however, stated "Yes I did see Smalles' collection, but in those days archaeological artifacts were 'illegal' and he did not present any gold objects in his collection for my perusal". in the grave. It is most unfortunate that due to its initial disturbance, the all important Original Gold Burial M1, A620 and its contents has never been properly dated ${ }^{14}$. Since gold cannot be radiometrically dated and the skeletal remains associated with this grave are too fragmentary for radiocarbon analysis, correct dating of the grave depended on the other objects found there (STEYN 2007: 141).

Fingerprinting of a number of gold artefacts from Mapungubwe Hill was done by the Anglo-American Research Laboratories in 1998 using the AARL gold fingerprinting technology, but none of the artefacts tested were from the Original Gold Burial M1, A620 and consequently the results have little bearing on the gold from this most important burial (GRIGOROVA et al. 1998: 99-102). In 2009 the University of Groningen used Accelerator Mass Spectrometry (AMS) to radiocarbon date grass-root fibres from two gold anklets from the Gold Skeleton grave M7, A623 on Mapungubwe Hill (WoOdBorne et al. 2009: 100-101). Although these fibres showed dates of manufacture in the $13^{\text {th }}$ century AD, these dates cannot haphazardly be transferred to the

14 From the evidence of Mr. J.C.O. (Jerry) van Graan (FouchÉ 1937: 2) most of the gold foil found in December 1932 from the Original Gold Burial M1, A620 was found near the surface and not from deep down, and when Professor Fouché examined and excavated the site a little later (Easter 1933) "more gold of similar nature to that found previously" came from near the surface (FoucHÉ 1937: 3-5). A photograph of the Original Gold Burial M1 A620, originally published by Fouché in 1937, clearly shows a clay bowl, the gold horn and other unidentifiable objects still in the grave, and also gives an indication of how shallow and near the surface the excavation was (see Fig. 4). Although erosion did play a role, it was not so extensive to remove meters of topsoil. 
Original Gold Burial M1, A620. The result is that we cannot put a date to iconic figures such as the gold rhino, gold bovine, gold feline and other gold foil fragments.

In 2011 Dr Linda Prinsloo (PrinsLoo et al. 2011: 3264-3277) of the University of Pretoria selected about two hundred coloured glass beads from the thousands of beads excavated on Mapungubwe Hill to study with Raman scattering. She identified at least seven different chromophores or pigments from the beads selected and these were then utilized to determine origins and periods of production. About 60 to 80 beads of each colour were eventually analysed. The most common beads associated with the burials - in particular the Original Gold Burial M1, A620 and the Gold Skeleton grave M7, A623) - are Mapungubwe oblates, (comprising $80 \%$ of all beads found at Mapungubwe), and consequently these featured very prominently in her investigation ${ }^{15}$. In her summary of the bead analysis from the burial sites on Mapungubwe Hill, Prinsloo (ibid.: 3273-3275) interpreted that many of the blue, green, white and striped beads were either from the $17^{\text {th }}$ to $18^{\text {th }}$ centuries and even as late as the early $19^{\text {th }}$ century ${ }^{16}$. The specific beads from the Original Gold Burial M1, A620 could unfortunately not be individually identified or dated as they were mixed in with all the other beads from Mapungubwe Hill, when the beads were taken out of their original containers and repacked by the museum staff in the 1990s (Linda Prinsloo 2012, pers. comm.). However, in the light of Prinsloo's findings concerning the later date of many of these beads and the fact that most of the graves on Mapungubwe Hill were shallow (20-25 $\mathrm{cm}$ from the surface), an $18^{\text {th }}$ or $19^{\text {th }}$ century date for the Original Gold Burial M1, A620 seems feasible ${ }^{17}$.

15 The volume of beads recovered from the gold burials on Mapungubwe Hill is staggering, since from the Gold Skeleton grave M7, A623 alone 26,037 beads were recovered of which 24,808 were black (PrinsLoo \& Colomban 2008: 79). Important amongst these beads are the small seed beads $(2-3.5 \mathrm{~mm})$ also known as the Mapungubwe oblates, comprising brilliantly coloured beads (cobalt, blue, orange, black, yellow, plum, turquoise and green) and manufactured by the drawn method.

16 TouRní et al. (2010: 6, 9, 18, 24 \& 26) provides a complete database of all the beads examined with photographs, Raman spectra and information of the provenance on the Internet. Here it is indicated that blue beads from boxes C0055 (1934) and C0037 (1940), green beads from box C0241 (1934) and white beads from box C0001 (1940) were all European beads from the $17^{\text {th }}$ to $18^{\text {th }}$ centuries and blue beads containing lazurite from boxes C0241 (Gold Skeleton grave M7, A623 1934) and C0039, as well as striped beads containing arsenate from box C0001 (1940) were all from the early $19^{\text {th }}$ century.

17 In November 1934 Professor D.E. Malan, a zoologist from the University of Pretoria, went to Mapungubwe Hill to report on the burials and in his report in 1937 he mentioned that all the graves were shallow (within about 8-10 inches or 20-25 cm from the surface) (STEYN 2007: 141). With regard to the shallowness of the graves on Mapungubwe Hill, see also footnote 14 above.

\section{Gold fragments from the Original Gold Burial M1, A260}

From the earliest records it is apparent that the archaeologists believed that all the gold foil fragments from the Original Gold Burial M1, A260 originally covered wooden cores, which had totally perished over time, since small nail holes were found all over them. Apart from the three restored animal figurines there are additionally more than 40 irregular gold foil fragments in the Mapungubwe collection. Andrew OdDy (1984: 70-78) from the Conservation Division of the British Museum carefully examined the Mapungubwe gold foil artefacts and with regard to the gold rhinoceros wrote in 1984 that it had "been shaped mainly by creasing, but also slightly by repoussé hammering. In particular, the hips of the front legs have been delineated nicely. The head and horn are both made from separate pieces of sheet, and the overall shape of the animal was achieved mainly by pressing the foil over a wooden carving and holding it in place with gold pins. The ears are made from slightly thicker foil and the tail has been hammered from a nugget and decorated by making incisions near the end with a sharp tool. It is the presence of significant numbers of gold pins among the finds from Mapungubwe which prove that the original carvings were of wood, rather than ivory, as the pins would be too soft for use with a hard substrate" (ibid.: 71). MEYER (1998: 203) explained that the gold foil was made by hammering the gold into 0.2 to $0.3 \mathrm{~mm}$ thin sheets on a stone anvil, as suggested by the textured inner surface of the foil, and it was then folded and hammered onto wooden carvings and tacked into position by small gold tacks or pins around the edges.

No fragments of the wood to which these figurines were attached have survived from the Original Gold Burial M1, A620, but the fact that Captain Guy GARDNER (1963: 20,151) found a badly charred carved wooden door in area B.5.S.1 on the Hill in 1939 is proof that the technical skill to do wood carving existed on Mapungubwe Hill in early times. Further, the fact that the inhabitants made use of wooden bowls on Mapungubwe Hill is confirmed by a reference to a "wooden vessel" found with skeleton M6 (field no. 11) by FoucHÉ (1937: 149), who states that "associated with these remains are charcoal fragments of a wooden vessel. The rim is bevelled from both faces and seems to have been undercut. Other fragments of the vessel show remains of an incised pattern. There are also evidences of iron ornaments".

The University of Pretoria eventually decided to find an expert to piece the various foil fragments together and in 1999 Marilyn Hockey, Senior Metals Conservator at the British Museum, meticulously restored the gold rhinoceros, then in 2000 the gold bowl (STEYN 2007: 141). From the restored rhino it became very obvious that originally the figurine must have been carved in wood and covered with a sheet of thin gold foil and that 

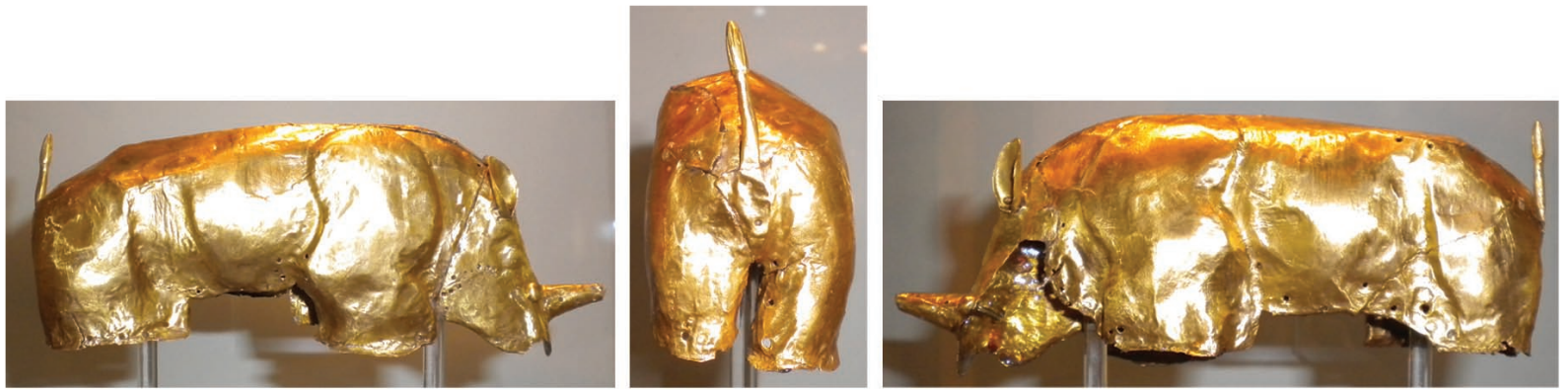

Fig. 5. The gold foil of the rhino from the Original Gold Burial M1, A620 seen from both sides and from the back.
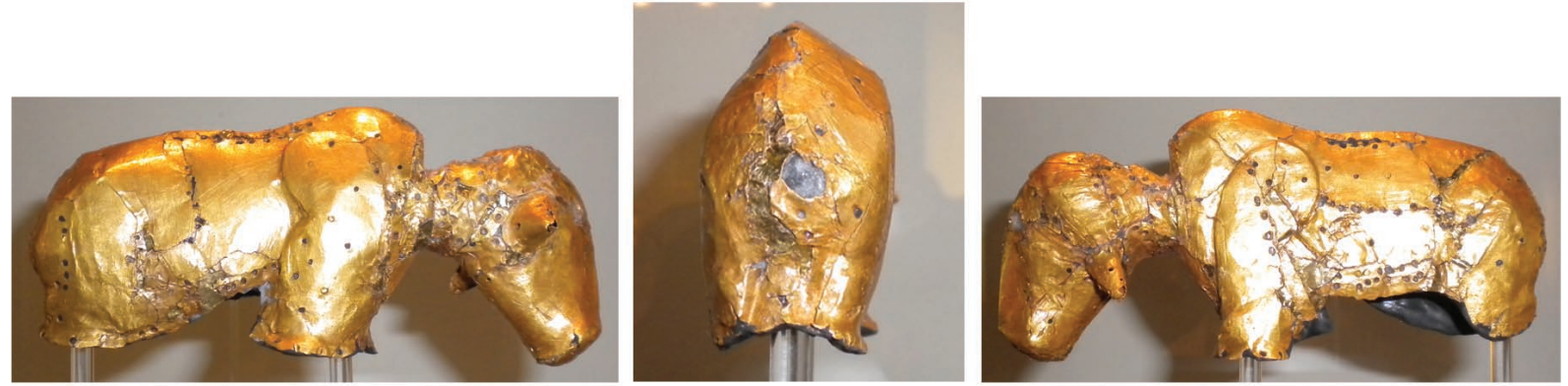

Fig. 6. The gold foil of the bovine from the Original Gold Burial M1, A620 seen from both sides and from the back.
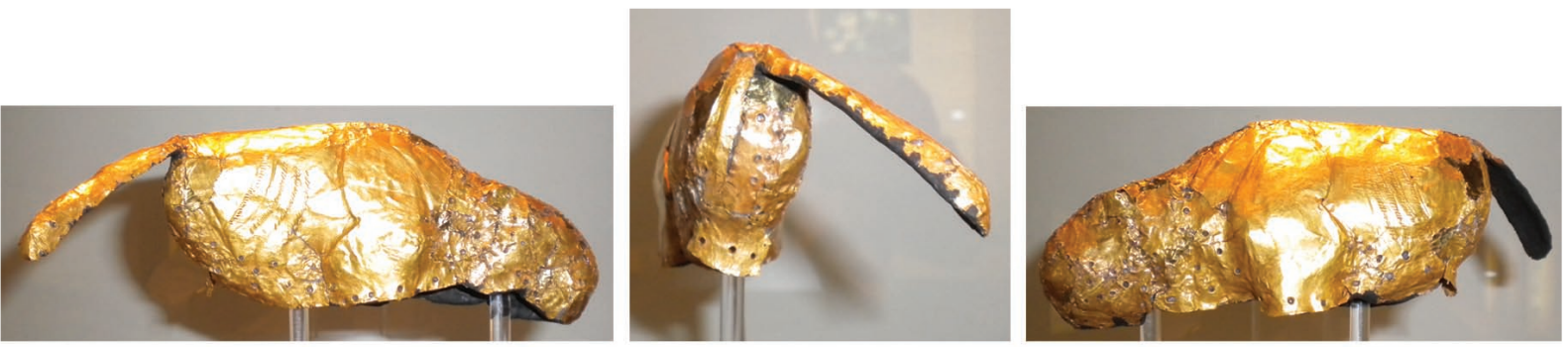

Fig. 7. The gold foil of the feline from the Original Gold Burial M1, A620 seen from both sides and from the back.

it must have been fixed to a flat wooden base, as there were small holes in the outward-flanged feet of the rhino. In 2009 the University of Pretoria meticulously pieced together the bovine and the feline (leopard) — as well as other fragments, working through the Mapungubwe Gold Conservation Project in association with the Metals Conservation Department at the South African Institute for Objects Conservation in the Eastern Cape (TILEY-NEL 2009: 3). Again it was very obvious from these restored pieces that they must originally have been nailed to a flat surface, because, like the gold rhino, the outward-flared legs of these animals have small nail holes in the gold foil. The remains of yet another animal figurine, most likely an elephant, still remain to be pieced together in future.

From a closer view of the $55 \mathrm{~mm}$ high rhinoceros (Fig. 5), it seems that two finely annealed gold foil sheets were shaped over a sculpted wooden core by folding and creasing them and then hammering them in place with small gold nails along the edges. Forger nails were used for the ears, two rounded gold nails for the eyes and a single folded horn is centred between the eyes. The small nail-holes in the outward-flared bases of the short stubby legs are an indication that the figurine was at one or other time attached to a flat surface. The head of the $55 \mathrm{~mm}$ high gold bovine (Fig. 6) was recovered intact, but the rest of the figure was made up of about forty fragments. Like the rhino, the gold foil was shaped over a wooden core with many golden tacks holding the pieces in place. This roughly formed figurine has a prominent hump on its back, the mouth and nostrils are clearly incised into the foil and two cone-shaped down-turned horns are attached by small gold nails. Again the feet of this figure are flared outward with small tack holes on the edges as if they were made to be attached to a flat surface. The $47 \mathrm{~mm}$ high gold stalking feline (Fig. 7) is made up of about thirty-six fragments. The hind legs are tucked in under 

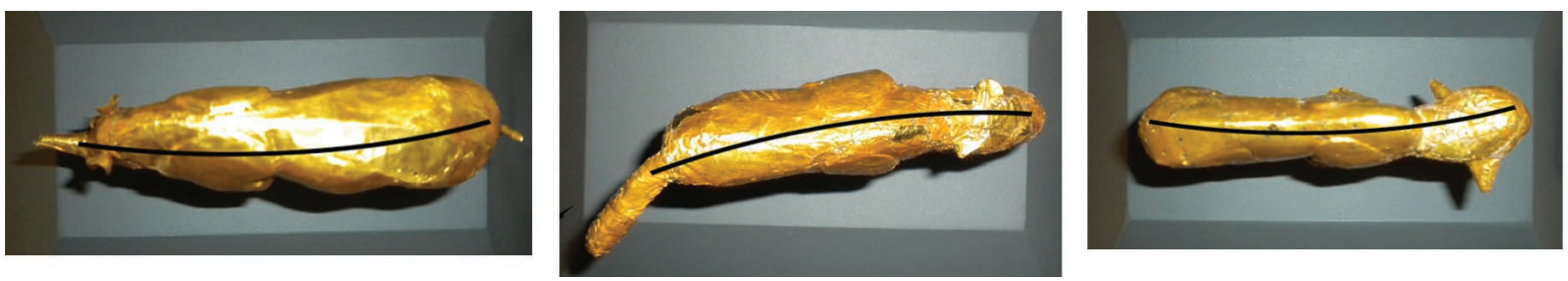

Fig. 8. The gold rhino, gold bovine and gold feline from the top with a $590 \mathrm{~mm}$ radius arc superimposed on them.

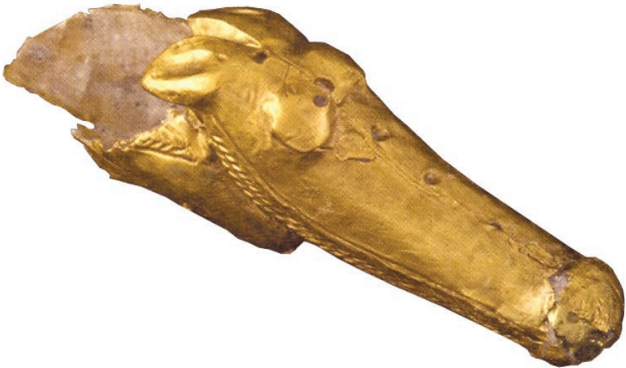

Fig. 9. Gold crocodile head $56 \mathrm{~mm}$.

the body, there is a long broadened tail and four rows of incised ribs are visible on the sides of the torso. The nail holes in the outward-flared fore-legs are again an indication that this figurine was also attached to a flat surface. The fourth figure, presumably an elephant or probably some other sib figurine, is completely fragmentary, yet parts such as the torso, legs and possibly the tusks can be identified. A fragment looking like two large bull-horns possibly represent the tusks of an elephant.

Due to the fact that the positions of these gold relics were not properly registered on excavation, and since the surface to which these gold foil fragments were attached no longer exists, a series of questions have always remained outstanding. What were the gold relics part of? Did they all form part of a single object or were they individual objects? Why were they buried with the specific individual in the Original Gold Burial M1, A620? What role did they play in the original society which made them?

\section{A Mapungubwe divining bowl}

While carefully studying the many fragments of gold foil and the restored rhino, bovine and feline from the Mapungubwe collection at the University of Pretoria, the author noticed that similar types of images, symbols and shapes are found on the rims and bases of all the divining bowls discussed. It was noticed that, with regard to style and iconography, the gold figurines all show the same conception and carving technique and are all of the same size. There is compelling evidence that the gold foil animal figurines once covered carved wooden core figures, and it is most probable that they were carved by the same artist, as the

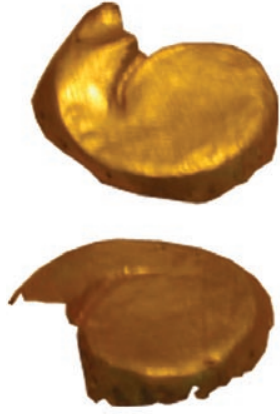

Fig. 10. Gold scrolls of the carved handles on the base of the divining bowl. way in which the forelegs of the rhino are modelled is identical with the modelling of the forelegs of the other animals. This, together with the fact that these objects all came from the same grave, gave rise to the idea that they probably formed part of the same object and, given the parallels noted above with known divining bowls, that this object could have been a large divining bowl. The gold rhinoceros, gold bovine, gold feline and the fragmentary figure of a probable elephant as well as the two circlets and other fragments may have formed the sib images and other symbols on the flattened rim of a large Mapungubwe divining bowl.

What started off as a somewhat speculative hypothesis eventually developed into a firmly established theory which gained credibility as closer inspection of the gold fragments provided more evidence. The most compelling evidence that these figures come from the flat rim of a round bowl is that when each figure is viewed from above their centre-line is not straight but slightly curved and each figure has been slightly flattened to stand on the narrow edge of the rim of the bowl (Fig. 8). Also, according to tradition, a crocodile should be found in the bed of the divining bowl. A beautiful three-dimensionally shaped $56 \mathrm{~mm}$ long head of a crocodile (Fig. 9) is part of the fragments from the Original Gold Burial M1, $A 620$ and at present in the Mapungubwe collection. It was formed from two pieces of gold foil held in place with gold nails on a wooden core. The head shows a rounded snout, bulging eyes and a double "row of teeth has been applied by rubbing a pointed tool on to the gold to make indentations" (ODDY 1984: 72). This was most likely the head of the crocodile, which was in the Smalle collection. There seems to have been a strict order in which the sibs and other images were arranged on the rim of the bowl. If these animal figurines were placed in the same order as those on the old Zimbabwe and other divining bowls, the bovine would be directly opposite the elephant, with the snout of the crocodile facing the elephant. Other fragments such as two scrolls (Fig. 10), two 


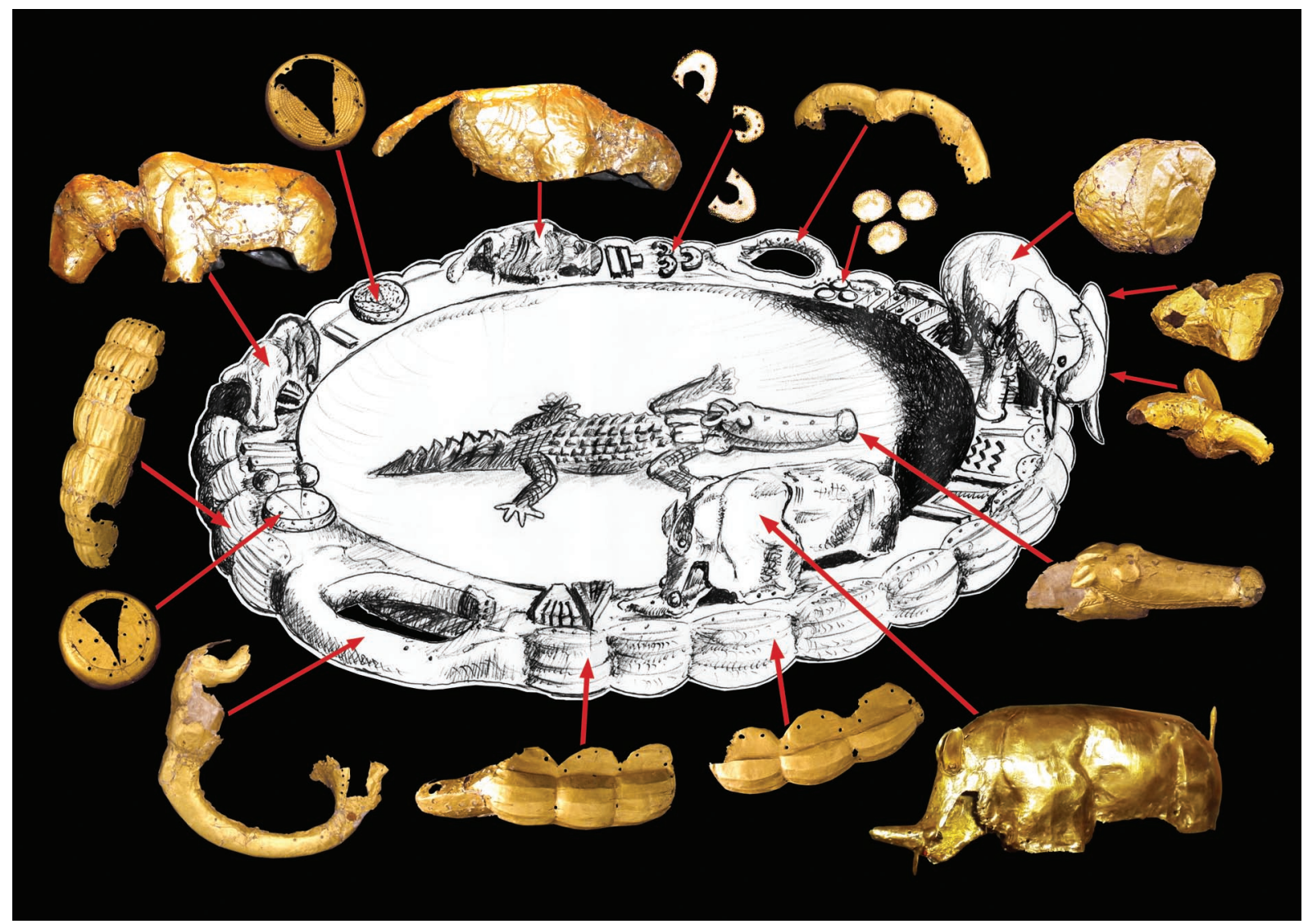

Fig. 11. View of the proposed Mapungubwe divining bowl with the gold foil fragments and figurines in their relevant places.

Fig. 12. Gold horn for the eye medicine $83 \mathrm{~mm}$.

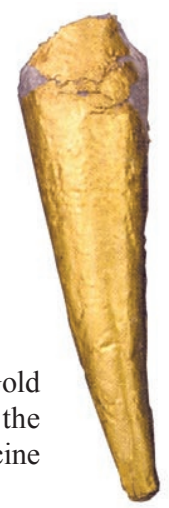

curved handle-like ornaments, a number of repoussé edgeplates, four half-circles with embossed concentric rings on two doughnut-like circlets $^{18}$, twenty seven smaller gold foil fragments and the many gold nails may all have formed part of the golden covering of an elaborately carved divining bowl (see Fig. 11). As in the case of the Zimbabwe bowl these scrolls formed the handles on the base of the bowl. The two handle-like ornaments can only have been handles on the rim and the repousséd edge-plates formed the outer edge of such an elaborately carved divining bowl.

18 Concerning these circlets Oddy noted the following: "Finally, among the gold foil pieces are some semi-circular ones which have both scribed and punched designs. Only a simple, round punch, with a diameter of $0.3 \mathrm{~mm}$, was used, but it was applied to the back of the sheet to give rows of dots, and another tool was then used to scribe lines between the dots on the front of the foil" (ODDY 1984: 72).
Among the other objects found in the Original Gold Burial M1, A620 on Mapungubwe Hill are further items that could confirm that some of the fragments were part of a diviner's divining equipment. A small golden horn-like object (Fig. 12) could have been the horn in which the mungoma kept his eye medicine. A pipe-shaped tubular decorative ornament with a shaped knob (Fig. 13) and with rows of chevron decorations on the sides was likely a piece of an elaborate whistle on which the mungoma blew when the seeds were dropped onto the water. The gold foil bowl of 144 mm diameter (Fig. 14), which also came from the Original Gold Burial M1, A620 originally covered a hollowed wooden bowl. This was supposedly the bowl with which the diviner poured the water into the larger divining bowl. A single piece of gold foil was folded over a thin wooden bowl with the upper edges hammered over the edge of the bowl and the foil attached by small gold nails along

Fig. 13. Gold whistle $87 \mathrm{~mm} \times 30 \mathrm{~mm}$. 


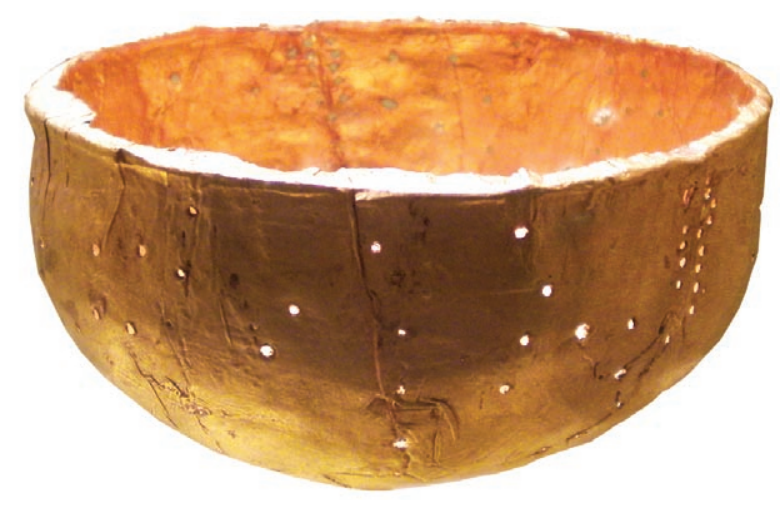

Fig. 14. The gold bowl from the Original Gold Burial M1, A620 on Mapungubwe Hill.

the sides. Tiley-Nel (2009: 12) notes that "a circular wear-mark or impression" surrounds some of the tack holes pointing to the presence of "some stud or decorative feature". Although this bowl was found lying near the cranium of the individual with whom it was buried, it is much too small to be a headdress.

\section{Conclusion}

From an iconographic and stylistic point of view the many fragments in the Mapungubwe gold collection of the University of Pretoria support the idea that they were all part of a single source object. Since the use of divining bowls has always been part of an ancient tradition amongst the diviners of the BaKaranga or Western Shona, BaVenda and VaLemba, it seems sensible to argue that such a source object should be a divining bowl and analysis of the artefacts seems to bear this conclusion out. The consequences of such an assumption for who the original occupiers of Mapungubwe Hill were become far-reaching. It can, however, explain the awe in which the Hill was held through the ages. Like with the divining bowl, the people were made to believe that they would become blind or even die if they set their eyes upon it. Like the divining bowl which had a single mafhoro or entrance gate to the khoro (gathering place), Mapungubwe Hill could only be accessed through a single entrance on the southern side. Any diviner who owned such an elaborately decorated gold covered divining bowl would have possessed immense power, would have been greatly feared by the local population and would undoubtedly have been considered a "Great One".

\section{Acknowledgements}

I am grateful to Sian Tiley-Nel, curator of the Mapungubwe Museum, for her help and valuable insights with regard to the background to the Mapungubwe gold. The photos to Figures 5-14 were taken by kind permission of the Mapungubwe Museum. I also want to thank Professors Innocent Pikirayi and Andrie Meyer for advice, Professor Judith Sealy, Professor Chris Boonzaaier, Dr Linda Prinsloo, Dr Rayda Becker, Mr Sidney Miller and Mrs Smalle for information and my wife, Heleen, for correcting and proofreading the text. I am also grateful to the two reviewers who helped to improve this paper.

\section{References}

Bent, J.T. 1896 (1969). The Ruined Cities of Mashonaland. Books of Rhodesia, Bulawayo, Rhodesiana Reprint Library, vol. 5, facsimile reproduction of the third edition. Longmans, Green \& Co., London.

Cooke, C.K. 1985. Magical, fertility and divining objects from Zimbabwe and adjacent areas. Cookeia, Zimbabwe 1 (3), $27-48$.

Davis, S. 1955. Divining bowls: their uses and origin. Some examples, and parallels from the ancient world. Man 55, 132-135. http://dx.doi.org/10.2307/2794593

Fouché, L. (ed.) 1937. Mapungubwe. Ancient Bantu Civilization on the Limpopo. Cambridge University Press, Cambridge.

Gardner, G.A. 1963. Mapungubwe. Report on Excavations at Mapungubwe and Bambandyanalo in Northern Transvaal from 1935 to 1940. Volume II. J.L. van Schaik Ltd., Pretoria.

Grigorova, B., Smith, W., Stülpner, K., Tumilty, J.A. \& Miller, D. 1998. Fingerprinting of gold artefacts from Mapungubwe, Bosutswe and Thulamela. Gold Bulletin 31 (3), 99-102. http:// dx.doi.org/10.1007/BF03214770

Huffman, T.N. 1996. Snakes \& Crocodiles. Power and Symbolism in Ancient Zimbabwe. Witwatersrand University Press, Johannesburg.

Kofi Agorsah, E. 2010. Religion, Ritual and African Tradition. AuthorHouse, Bloomington.

Kruger, J. 1999. Of wizards and madmen: Venda. Zwilombe SAMUS 19/20, 15-31. http://dx.doi.org/10.4314/samus. v19i1.6380

Loubser, J.H.N. 2008. Discontinuity between political power and religious status: mountains, pools, and dry ones among Venda-speaking chiefdoms of southern Africa. In: Whitley, D. \& Hays-Gilpin, K. (eds.), Belief in the Past: Theoretical Approaches to the Archaeology of Religion. Left Coast Press, Walnut Creek, pp. 189-208. 
Mack, J. 2007. The Art of Small Things. The British Museum Press, London.

Meyer, A. 1998. The Archaeological Sites of Greefswald: Stratigraphy and Chronology of the Sites and a History of Investigation. University of Pretoria, Pretoria.

Meyer, A. 2011. The Mapungubwe Archaeological project of the University of Pretoria. In: Tiley-Nel, S. (ed.), Mapungubwe Remembered. Chris van Rensburg Publications (Pty) Ltd., Melville, pp. 56-87.

Nettleton, A.C.E. 1984. The Traditional Figurative Woodcarving of the Shona and Venda. 2 vols. Unpublished Ph.D. Thesis. University of the Witwatersrand, Johannesburg.

Nettleton, A. 2000. Divining bowl. In: Mack, J. (ed.), Africa: Arts and Culture. The British Museum Press, London, pp. 188-189.

Oddy, A. 1984. Gold in the southern African Iron Age. A technological investigation of the Mapungubwe and other finds. Gold Bulletin 17 (2), 70-78. http://dx.doi.org/10.1007/ BF03214702

Peek, P.M. (ed.) 1991. African Divination Systems. Ways of Knowing. Indiana University Press, Bloomington.

Pikirayi, I. 2001. The Zimbabwe Culture: Origins and Decline of Southern Zambezian States. Altamira Press, Walnut Creek.

Prinsloo, L. \& Colomban, P. 2008. A Raman spectroscopic study of the Mapungubwe oblates: glass trade beads excavated at an Iron Age archaeological site in South Africa. Journal of Raman Spectroscopy 39, 79-90. http://dx.doi.org/10.1002/ jrs. 1816
Prinsloo, L., Tournié, A. \& Colomban, P. 2011. A Raman spectroscopic study of glass trade beads excavated at Mapungubwe hill and K2, two archaeological sites in southern Africa, raises questions about the last occupation date of the hill. Journal of Archaeological Science 38 (12), 3264-3277. http://dx.doi. org/10.1016/j.jas.2011.07.004

Robinson, K.R. 1959. Khami Ruins. Cambridge University Press, Cambridge.

Schoeman, A. 2011. Co-operation, conflict and the University of Pretoria Archaeological Committee. The early years of Mapungubwe archaeological research. In: Tiley-Nel, S. (ed.), Mapungubwe Remembered. Chris van Rensburg Publications (Pty) Ltd., Melville, pp. 88-101.

Stayt, H.A. 1968. The BaVenda. Frank Cass \& Co. Ltd., London.

Steyn, M. 2007. The Mapungubwe gold graves revisited. South African Archaeological Bulletin 62 (186), 140-146.

Tiley, S. 2005. Mapungubwe: South Africa's Crown Jewels. Sunbird Publications, Cape Town.

Tiley-Nel, S. 2009. Gold Treasures of Mapungubwe. A Companion Guide to the Mapungubwe Museum Gold Exhibition. University of Pretoria, Pretoria.

Tiley-Nel, S. (ed.) 2011. Mapungubwe Remembered. Chris van Rensburg Publications (Pty) Ltd., Melville.

Tournié, A., Prinsloo, L.C. \& Colomban, P. 2010. Raman classification of the glass Beads excavated on Mapungubwe Hill and K2, archaeological sites in South Africa. University of Pretoria Internal Report, HAI, arXiv.org/pdf/1012.1465.

Woodborne, S., Pienaar, M. \& Tiley-Nel, S. 2009. Dating the Mapungubwe Hill gold. Journal of African Archaeology 7 (1), 99-105. http://dx.doi.org/10.3213/1612-1651-10122 